\title{
TBK.m.117 ile Karşılaştırmalı Olarak TTK.m.1530 Uyarınca Borçlu Temerrüdünün İhtarsız Gerçekleşmesi
}

\author{
Mustafa Göktürk Yıldız
}

Öz

Türk Borçlar Kanunu'nun genel hükümler kısmında yer alan TBK.m.117/f.1'de, muaccel bir borcun borçlusunun alacaklının ihtarıyla temerrüde düşeceği belirtilmiştir. Aynı maddenin ikinci fikrasında ise temerrüt için ihtar şartının gerekmediği bazı haller düzenlenmiştir. Bununla birlikte temerrüt için alacaklının ihtarının gerekmediği haller TBK.m.117/f.2'de sayılanlar ile sınırlı değildir. TBK.m.117/f.2'ye göre daha özel nitelikteki düzenlemelerde de ihtarsız temerrüt hallerinin kabul edildiği görülebilmektedir. TTK.m.1530/f.2 ve f.4 hükümleri de bu özel düzenlemeler arasındadır. Söz konusu hükümlerde ihtarsız temerrüt hallerinin öngörülmesindeki amaç TBK.m.117/f.2'den farklıdır. Ayrıca TTK.m.1530/f.2'de ihtarsız temerrüt hallerinin meydana gelmesi için Türk Borçlar Kanunu’nun genel temerrüt hükümlerinde bulunmayan bazı koşullar kabul edilmiştir. Bu noktada cevaplandırılması gereken sorulardan biri bu koşulların kapsamı, bir diğeri ise f.2'deki koşulların TTK.m.1530/f.4 bakımından da aranıp aranmayacağıdır. Diğer yandan anılan düzenlemelerde yer alan koşullar ile temerrüdün ihtarsız gerçekleşeceğinin ifade edildiği hallerin bir kısmı genel hükümler ile büyük ölçüde benzerlik göstermektedir. Şu halde bunların genel hükümlerden farklarının bulunup bulunmadığı da ortaya koyulmalıdır. Çalışmamızda TTK.m.1530'da zikredilen ihtarsız temerrüt hallerinin varlığı için aranan koşullar ile ihtara gerek bulunmayan hallerin kapsamı TBK.m.117 ile karşılaştırmalı olarak ele alınacaktır.

\section{Anahtar Kelimeler}

Türk ticaret kanunu • Türk borçlar kanunu • Borçlu temerrüdü • İhtarsız temerrüt • Temerrüt faizi

The Occurrence of Debtor's Default without a Reminder According to Article 1530 of the Turkish Commercial Code, in Comparison with the Article 117 of the Turkish Code of Obligations

\begin{abstract}
In TCO Art. 117 par. 1, which is situated in the general provisions of the Turkish Code of Obligations, it is stated that the debtor of a due debt will be in default after being reminded by the creditor. However, according to TCO Art. 117 par. 2 , there are some cases where a reminder of the creditor is not necessary for default. On the other hand, the cases in which a reminder of the creditor is not required are not limited to those listed in TCO Art. 117 par. 2. It is possible that, in more particular regulations than par. 2, default without a reminder case is accepted. The provisions of TCC Art. 1530 par. 2 and par. 4 are included among these particular regulations.

The purpose of predicting some default without reminder cases in these particular provisions differs from TCO Art. 117 par. 2. Additionally, in TCC Art. 1530 par. 2, some conditions that are not included in the general provisions of the Turkish Code of Obligations have been accepted in order to default without a reminder cases to take place. At this point, one of the questions to be answered is the scope of these conditions and the other one is if these conditions are to be sought in terms of TCC Art. 1530 par. 4.

In the mentioned regulations, some of the conditions along with some of the cases, in which the default is occurred without a reminder, show a great similarity with the general provisions. Thus, it should also be stated whether they differ from the general provisions. In this article, to respond to those questions, the conditions required for the existence of default without a reminder cases mentioned in TCC Art. 1530, and the scope of those cases, will be considered in comparison with TCO Art. 117.
\end{abstract}

\section{Keywords}

Turkish commercial code $\bullet$ Turkish code of obligations $\bullet$ Default of debtor $\bullet$ Default without reminder $\bullet$ Default interest

\footnotetext{
Sorumlu Yazar: Mustafa Göktürk Yıldız (Dr.), Yalova Üniversitesi, Hukuk Fakültesi, Medeni Hukuk Ana Bilim Dalı, Yalova, Türkiye. Eposta: mustafa.yildiz@yalova.edu.tr
}

Atıf: Yıldız, Mustafa Göktürk; "TBK.m.117 ile Karşılaştırmalı Olarak TTK.m.1530 Uyarınca Borçlu Temerrüdünün İhtarsız Gerçekleşmesi”, İstanbul Hukuk Mecmuası, 76/1, 2018, 359-380. 


\section{I. İhtarsız Temerrüt Hallerinin Öngörülme Amacı}

\section{A. TBK.m.117 Bakımından}

TBK.m.117/f.1'de, "Muaccel bir borcun borçlusu, alacaklının ihtarlyla temerrüde düşer." denmek suretiyle, temerrüdün muacceliyetten itibaren değil de, kural olarak alacaklının ihtarından itibaren gerçekleşeceği kabul edilmiştir.

İhtar, alacak hakkının sağladı̆̆ ifayı talep yetkisinin olağan kullanma yöntemidir . Alacaklı ihtarla, borcun yerine getirilmesini istediğini borçluya bildirerek onu ifaya davet eder ${ }^{2}$.

İhtar, ifa zamanının belirsiz olduğu veya borçlu tarafından bilinmediği hallerde doğabilecek olumsuz neticelerden borçlunun korunmasını sağlar ${ }^{3}$. Borçlu, ihtar anından itibaren ifada gecikmenin borca aykırlık teşkil edeceğini ve ciddi sonuçlardoğurabileceğini anlamış olur' ${ }^{4}$. Burada borçlunun korunmasının sebebi alacaklıya karşı zayıf konumda olması değil, hukukî durumun açıklık kazanmasını bilmeye hakkı olmasıdır.

İhtarın borçluyu koruyucu işlevine rağmen, kanun koyucu TBK.m.117/f.2'de belirtilen hallerde temerrüdün oluşumu için ihtara gerek görmemiştir. Bunun altında yatan temel gerekçe, ihtarın sağladığı koruma işlevinin bazı hallerde işin niteliği gereği kendiliğinden gerçekleşmesi ve borçlunun ayrıca korunmasına lüzum bulunmamasıdır. Şöyle ki, ihtarsız temerrüt hallerinde, borca aykırılığın hangi andan itibaren gerçekleşeceği kendiliğinden anlaşılmakta ve borçludan bunu bilmesi beklenmektedir. TBK.m.117/f.2'de öngörülen ihtarsız temerrüt halleri üzerinden gidilecek olursa, borcun ifa edileceği gün birlikte belirlendiği veya taraflardan biri sözleşmede saklı tutulan bir hakka dayanarak usulüne uygun bir bildirimde bulunmak suretiyle belirlediği takdirde, bu günün geçmesiyle temerrüt kendiliğinden gerçekleşir. Dikkat edilirse, her iki durumda da ifa gününün belirlenmesinde borçlunun iradesi de rol oynamaktadır. Şu halde borçlu, alacaklının ifayı ne zaman beklediği ve ifa etmemenin hangi andan itibaren borca aykırılık teşkil ettiğini işin niteliği gereği kendiliğinden öğrendiğinden ayrıca uyarılmasına lüzum yoktur. Yine aynı düzenlemede haksız fiil failinin fiilin işlendiği, kötüniyetli sebepsiz zenginleşenin ise zenginleşmenin gerçekleştiği tarihte kendiliğinden temerrüde düşeceği belirtilmiştir. Zira bu gibi hallerde verdiği zararı gidermesi veya aldığını iade etmesi gerektiği zamanı bilmesi beklenen borçlu, çoğu zaman korunmayı hak etmez . Örneğin hırsız,

\footnotetext{
Andreas von Tuhr/Arnold Escher, Allgemeiner Teil des schweizerischen Obligationenrecht, Band II (mit Supplement), Schulthess Juristische Medien AG, 1984, s. 136 dn. 8; Nami Barlas, Para Borçlarının İfasında Borçlunun Temerrüdü ve Bu Temerrüt Açısından Düzenlenen Genel Sonuçlar, İstanbul, Kazancı Hukuk Yayınları No:105, 1992, s. 34.

Fikret Eren, Borçlar Hukuku Genel Hükümler, Ankara, Yetkin Yayınları, 2015, s. 1093; von Tuhr/Escher, s. 136;

Luc Thévenoz, in Luc Thévenoz, (Ed.)/Franz Werro (Ed.): Commentaire Romand, Code des obligations I, Art. 1-529 CO, Bâle, Helbing Lichtenhahn, 2012, Art. 102, N. 16; von Tuhr/Escher, s. 136.

4 Thévenoz, Art. 102, N. 17.

Burada çoğu zaman ifadesini kullanmamızın sebebi haksız fiil ve sebepsiz zenginleşme açısından kanun koyucunun bu tercihinin yerindeliğinin tartışmaya açık olmasıdır. Söz konusu tercihin değerlendirilmesi çalışmamızın sınırlarını
} 
şeyi çaldığı andan itibaren onu iade etmesi gerektiğini bilir. Bu sebeple ihtara gerek olmaksızın haksız fiil anından itibaren mütemerrit kabul edilerek beklenmedik hal sebebiyle şeye gelen zarardan sorumlu tutulur ${ }^{6}$. Kanunda öngörülmemesine rağmen doktrinde temerrüdün ihtarsız olarak gerçekleşeceğinin kabul edildiği hallerde de vaziyet pek farklı değildir. Zira bunların temelinde dürüstlük kuralı yatmakta ve borçlunun korunmasının gerekli olup olmadığı sorusuna somut olay bakımından cevap aranmaktadır. Örneğin borçlunun ihtara muhatap olmaktan bilerek kaçınması, borçlunun ifada bulunmayacağını kesin olarak beyan etmesi, ifa zamanını alacaklıdan ziyade borçlunun bilmesinin gerekmesinde olduğu gibi.

Buna karşılık TTK.m.1530'da düzenlenen ihtarsız temerrüt hallerinde kanun koyucunun farklı amaçlarla hareket ettiği görülmektedir. TTK.m.1530/f.2 ve f.4 uyarınca temerrüdün ihtarsız gerçekleştiği hallerin kapsamının belirlenmesi bakımından kanun koyucunun amacının tespit edilmesi önem arz etmektedir.

\section{B. TTK.m.1530 Bakımından}

TTK.m.1530'da ihtarsız temerrüt hallerine yer verilmesinin sebebinin TBK.m.117/ f.2'den oldukça farklı olduğu görülmektedir. Gerçekten de maddenin Türkiye Büyük Millet Meclisine sunulan önergesinin gerekçesinde ${ }^{7}$ aynen şu ifadelere yer verilmiştir: “... Hüküm üreticileri, KOBİ'leri ve fatura ya da eşdeğer ödeme talepleri karşılığı hizmet veren ticari işletmeler ile kişileri, şartları dayatma konumları güçlü ticari işletmeler, özellikle market, süper market, hiper market gibi alışveriş merkezleri karşısında korumaktadır. ... Çoğunlukla finansal açıdan pek de güçlü olmayan üretici, KOBI ve benzeri işletmelerin teslim ettikleri malların ve hizmetlerin bedellerini zamanında alarak ekonomik yapılarını güçlendirmelerine yardımcı olmak, pazar ekonomisine hakim yeni bir yaklaşımdır. AT yönergesi ve değişikliği bu yaklaşımın somut örneğidir.

Yönergenin giriş kısmında da belirtildiği gibi birçok büyük ve güçlü ticari işletme geç ödemeyi bir finansman aracı olarak kullanmaktadır. Ancak bu araç marketlere, süper marketlere, hiper marketlere ve benzeri güçlü ticari işletmelere mal ve hizmet verenleri çok güç durumda bırakmakta, finansal durumlarını sarsmakta, hatta iflasa da sürüklemektedir. Hüküm bu kötü uygulamanın önüne geçmek için öngörülmüştür.”

aşmaktadır. Bu konuda Haluk Nami Nomer, "Haksız Fiil ile Sebepsiz Zenginleșmeden Doğan Alacaklarda Borçlunun Temerrüdü İçin İhtar Gerekir mi?”, Prof. Dr. Rona Serozan'a Armağan, Cilt II, İstanbul, On İki Levha, 2010, s. 13031313, künyeli esere bakılabilir. Burada kısaca belirtmek gerekirse, yazara göre gerek haksız fiilden gerekse sebepsiz zenginleşmeden doğan borçlarda kural olarak temerrüt için ihtar şartı aranmalıdır. Bu nedenle her somut olayda dürüstlük kuralı uyarınca ihtarın gerekip gerekmediğinin değerlendirilmesine imkân tanıyan bir düzenlemenin getirilmesi daha yerinde olacaktır (Nomer, s. 1306-1308 ve s. 1309 ve 1313). Diğer yandan dürüstlük kuralı çerçevesinde yapılacak değerlendirmede de esasen borçlunun korunmayı hak edip etmediğine, ihtarın işlevinin işin niteliği gereği kendiliğinden gerçekleşip gerçekleşmediğine bakılacaktır.

von Tuhr/Escher, s. 140-141.

Türkiye Büyük Millet Meclisi Genel Kurul Tutanağı, 23. Dönem 5. Yasama Y1lı 51. Birleşim 13/Ocak/2011 Perşembe, s. 127. Tutanak için bkz. (Çevrimiçi) https://www.tbmm.gov.tr/develop/owa/tutanak_sd.birlesim_baslangic?P4=20839\&P5= B\&PAGE1=127\&PAGE2=\&web_user_id=16607146, 22.07.2018. 
Buna göre TTK.m.1530'un amac1; üretici, KOBİ ve fatura ya da eş değer ödeme talebi karşılığında mal veya hizmet sağlayan ticari işletmeler ile kişileri, güçlü konumda olan market, süper market, hiper market gibi büyük işletmelere karşı korumaktır. Bu gerekçe hem TTK.m.1530/f.2 hem de TTK.m.1530/f.4’te öngörülen ihtarsız temerrüt halleri için geçerlidir. Şöyle ki, özellikle büyük işletmeler karşısında zayıf konumda olan sözleşme tarafları mal veya hizmet tedariki borçlarını ifa etmiş olmalarına rağmen, karşı edim alacağı olan para alacaklarını alamamış olabilirler. Esasında para alacaklıları böyle bir durumda ihtar göndermek suretiyle borçluyu temerrüde düşürmek ve alacaklarını tahsil edinceye kadar ticari faiz işlemesini sağlamak imkânına sahiptirler. Fakat nasıl olsa alacağım ödenir, ihtilâf çıkarsa büyük işletmeyle baş edemem gibi düşünceler ve karşı taraf ile ticari ilişkilerin bozulması riskinden kaynaklanan müşteri kaybetme korkusu zayıf konumda olan kişilerin ihtar göndermekte veya ihtar yerine de geçecek olan eda davası açmakta çekingen davranmalarına sebebiyet verebilmektedir. Bıçak kemiğe dayanıp da ihtarda bulunulduğunda veya eda davası açıldığında ise, bu ana kadar geçen sürede ihtarda bulunulsaydı talep edilebilecek olan temerrüt faizinden mahrum kalınmaktadır.

Sonuç olarak TTK.m.1530'da ihtarsız temerrüt hallerine yer verilmesindeki temel amaç, TBK.m.117/f.2'dekinden farklıdır. Hemen yukarıda da belirttiğimiz üzere TBK.m.117/f.2'de temerrüt için ihtara gerek görülmemesinin temelinde, hükümde öngörülen hallerde ihtarın borçluyu koruyucu işlevinin kendiliğinden gerçekleşmesi ve borçlunun korunmasına gerek olmaması yatmaktadır. Oysa TTK.m.1530'da kanun koyucunun zayıf taraf olarak gördüğü para alacaklısını korumak amacıyla hareket ettiği görülmektedir. TTK.m.1530/f.2 ve f.4 tatbik edilirken, kanun koyucunun bu amacı daima göz önünde tutulmalıdır.

\section{II. İhtarsız Temerrüt İçin Aranan Koşullar}

\section{A. Genel Olarak}

TBK.m.117, temerrüdün koşulları ve ihtarsız temerrüt hallerinin gerçekleşmesi açısından tarafları ve konusuna bakılmaksızın her türlü borç ilişkisini kapsayııı bir dille kaleme alınmış ve borçlu ifayı geciktirmede kusursuz da olsa temerrüdün gerçekleşebileceğini kabul etmiştir. Oysa TTK.m.1530/f.2 uyarınca,

"Ticari işletmeler arasında mal ve hizmet tedariki amactyla yapılan işlemlerde, alacakll, kanundan veya sözleşmeden doğan tedarik borcunu yerine getirmiş olmasına rağmen, borçlu, gecikmeden sorumlu tutulamayacağı hâller hariç, sözleşmede öngörülmüş bulunan tarihte veya belirtilen ödeme süresinde borcunu ödemezse, ihtara gerek olmaksızın temerrüde düşer."

Görüldüğü gibi hükümde borçlunun ihtara gerek bulunmaksızın temerrüde düşmesi için genel ilkelerden ayrılan bazı koşullara yer verilmiştir. Bunlar; işlemin ticari işletmeler arasında olması, mal ve tedarik amacıyla yapılan bir işlemin bulunması, 
para alacaklısının kendi borcunu yerine getirmiş olması ve borçlunun gecikmeden sorumlu tutulabilmesi şeklinde sıralanabilir. Bu koşullar TTK.m.1530/f.4'deki ihtarsız temerrüt halleri için de aranacaktır ${ }^{8}$.

Anılan koşulların hiç biri Türk Borçlar Kanunu'nun genel hükümlerinde zikredilmemiştir. Şu halde her bir koşulun incelenerek, kapsamları ve genel hükümlerden ne ölçüde ayrıldıklarının belirlenmesi önem arz etmektedir.

\section{B. TTK.m.1530 Özelinde Aranan Koşullar}

1. İşlemin ticari işletmeler arasında olması. TBK.m.117' de borçlu temerrüdünün şartlarına ilişkin olarak işlemin tarafları açısından bir sınırlamaya gidilmemiştir. Buna karş1lık TTK.m.1530/f.2, işlemin "ticari işletmeler arasında” yapılmış olmasını şart koşmuştur. Şu halde düzenlemenin lafzı dikkate alınacak olursa, söz konusu hüküm uyarınca temerrüdün ihtarsız gerçekleşebilmesi için işlemin her iki tarafında da ticari işletmenin yer alması gerekmektedir. Ancak ticari işletmenin kendisine ait bir kişiliği bulunmadığından haklara ve borçlara ehil olamaz. Bu noktada hükmün taraflar bakımından uygulama alanı hususunda temel olarak iki görüş ileri sürülmüştür. Birinci görüşe göre ${ }^{9}$ bu ifade ile tacirler arasında yapılan ve iki tarafin da ticari işletmesiyle ilgili işlemler kastedilmektedir ${ }^{10}$. İkinci görüş ise ${ }^{11}$ burada işlemin her iki tarafın ticari işletmesiyle ilgili olmasının ifade edildiğini ileri sürmektedir. $\mathrm{Bu}$ son görüş uyarınca ticari işletme işletmesine rağmen kendileri tacir sayılmayan kişiler $^{12}$, özel hukuk hükümleri çerçevesinde yürüttükleri ticari işletme faaliyetleri açısından, TTK.m.1530 kapsamında değerlendirilebilir ${ }^{13}$. Zira TTK.m.1530/f.2 tacir olmaya değil ticari işletmeyle ilgili olmaya sonuç bağlamıştır ${ }^{14}$. Buna karşılık kamu hukukuna göre yürütülen faaliyetler TTK.m.1530 kapsamına girmez.

Görüldüğü gibi her iki görüşün de ortak noktası işlemin ticari işletmeyle ilgili olmasıdır. Kanaatimizce ticari işletme ile ilgili olma konusunda TTK.m.3'te kabul edilen prensiplerden faydalanılabilir. Buna göre ticari işletme ile ilgili olma kavramı geniş yorumlanmalı ve doğrudan ya da dolaylı olarak ticari işletmeyi ilgilendiren her türlü işlem bu kapsamda değerlendirilmelidir.

\footnotetext{
Gecikmeden sorumluluk koşulu bakımından aynı yönde: Hüseyin Ülgen/Mehmet Helvacı/Abuzer Kendigelen/Arslan Kaya/N. Füsun Nomer-Ertan, Ticari İşletme Hukuku, İstanbul, On İki Levha, 2015, (Ülgen), s. 318, N. 625. Ayrıca bkz. aşağıda III/B/1.

9 Serkan Ayan, “6102 sayılı Türk Ticaret Kanunu'nun 1530. Maddesi Gereğince Borçlunun Temerrüdü”, Dokuz Eylül Üniversitesi Hukuk Fakültesi Dergisi (Prof. Dr. Burhan Ceyhan’a Armağan Özel Sayısı), C: 12, Yı1: 2010, s. 732-733.

10 Yine bu eğilimde: Ülgen v.d. (Ülgen), s. 315, N. 618. Yazara göre hüküm sadece tacir-tacir işletmeleri açısından uygulanabilir.

11 Yeşim M. Atamer/Gül Okutan-Nilsson, "Para Alacaklısının Geç Ödemelere Karşı Korunmasına İlişkin Yeni TK M. 1530 Düzenlemesi ve Uygulama Alanı”, Banka ve Ticaret Hukuku Dergisi, C: XXIX, S. 3’ten ayrı bas1, Y11: 2013, s. 64-65.

12 TTK.m.16/f.2'ye göre, "Devlet, il özel idaresi, belediye ve köy ile diğer kamu tüzel kişileri ile kamu yararına çalışan dernekler ve gelirinin yarısından fazlasın kamu görevi niteliğindeki işlere harcayan vakıflar, bir ticari işletmeyi, ister doğrudan doğruya ister kamu hukuku hükümlerine göre yönetilen ve işletilen bir tüzel kişi eliyle işletsinler, kendileri tacir sayılmazlar."

13 Atamer/Okutan-Nilsson, s. 65.

14 Atamer/Okutan-Nilsson, s. 65.
} 
Yine hükmün lafzına bakılacak olursa, küçük veya orta çaplı bir işletmenin büyük çaplı bir işletmeye olan para borcunu ödemede gecikmesi halinde bile TTK.m.1530 uygulama alanı bulabilecek, böylece büyük çaplı işletme küçük ölçekli bir işletmeye karşı genel hükümlerden daha iyi bir korumaya kavuşabilecektir. Oysa yukarıda ifade edildiği üzere maddenin getiriliş amacı esas olarak işlemin zayıf tarafını korumaktır. $\mathrm{Bu}$ nedenle kanaatimizce hükmün amaca uygun olarak yorumlanması gerekir. Buna göre söz konusu düzenleme her şeyden önce alacaklının küçük veya orta ölçekli işletme; borçlunun ise büyük ölçekli işletme olduğu hallerde uygulanacaktır. Öte yandan para alacaklısının büyük ölçekli işletme, borçlunun ise büyük ölçekli işletme niteliğinde olmayan bir işletme olması hallerini anılan düzenlemenin dışında tutmak gerekir. Burada çözülmesi gereken bir diğer sorun da her iki tarafin da büyük ölçekli işletme olması halinde ne şekilde hareket edileceğidir. Kanaatimizce bu durumda da madde kural olarak uygulanabilmelidir. Büyük işletme niteliğindeki bir işletmenin özellikle piyasaya hâkim konumdaki büyük işletmeler karşısında zayıf konumda olması ve sözleşme hükümlerinin kendisine dayatılması pekâlâ mümkündür.

Diğer yandan madde yorumlanırken TTK.m.1530'un diğer fikraları da göz önünde tutulmalıdır. $\mathrm{Bu}$ bağlamda TTK.m.1530/f.5'te şu şekilde bir düzenleme kaleme alınmışıฺr: "Sözleşmede öngörülen ödeme süresi, faturanın veya eş değer ödeme talebinin veya mal veya hizmetin alındiğ veya mal veya hizmetin gözden geçirme ve kabul usulünün tamamlandı̆̆ tarihten itibaren en fazla altmış gün olabilir. Şu kadar $k i$, alacakl aleyhine ağır bir haksız durum yaratmamak koşuluyla ve açıkça anlaşmak suretiyle taraflar daha uzun bir süre öngörebilirler. Ancak alacaklinin küçük yahut orta ölçekli işletme (KOBI) veya tarımsal ya da hayvansal üretici olduğu veya borçlunun büyük ölçekli işletme sıfatını taşıdığı hâllerde ${ }^{15}$, ödeme süresi, altmış günü aşamaz."

Hükümde konumuz açısından bizi ilgilendiren kısım fikranın son cümlesidir. Şöyle ki, düzenlemede tarımsal veya hayvansal üreticinin faaliyetlerinin bir işletme kapsamında olması gerektiği belirtilmemiştir. Şu halde, tarımsal ve hayvansal üreticiler, faaliyetleri bir işletme kapsamında olmasa dahi maddenin avantajlı düzenlemelerinden yararlanabilirler. Böylelikle tarladan topladığı mahsulünü bir süpermarkete satan çiftçi, bir ticari işletme işletmiyor olsa dahi, TTK.m.1530'dan yararlanabilir. Diğer yandan küçük veya orta çaplı bir işletme kapsamında faaliyetlerini yürüten üreticiler, tarımsal veya hayvansal üretici olmasalar bile, yine hükmün kapsamında değerlendirilmelidir.

Hükümde yer alan, “... veya borçlunun büyük ölçekli işletme sıfatını taşıdı̆̆ hâllerde ...” ifadesindeki "veya” bağlacının "ve" olarak anlaşılması gerektiği yönünde: Abuzer Kendigelen, Yeni Türk Ticaret Kanunu, Değişiklikler, Yenilikler ve İlk Tespitler, 2. Bası, İstanbul, On İki Levha, 2012, s. 605; Atamer/Okutan-Nilsson, s. 50; Ayan, s. 747. Maddenin mevcut ifadesiyle değerlendirilmesi gerektiği yönünde: Pınar Çağlayan, "Avrupa Birliği Yönergeleri ve Alman Hukukundaki Deneyimler Işığında Mal ve Hizmet Tedarikinde Geç Ödemenin Sonuçları (TTK MD. 1530)", Banka ve Ticaret Hukuku Dergisi, C: XXVII, S. 2, Y11: 2011, s. 232; H. Ali Dural, "Ticari İşletmeler Arasındaki Mal ve Hizmet Tedariki Sözleşmelerine İlişkin Yeni Ticaret Kanunu'nun 1530. Maddesi”, Yeni Türk Ticaret Kanunu'nun Ticari İşletme Hukuku Alanında Getirdiği Yenilikler Sempozyumu (25-26 Kasım 2011), Kadir Has Üniversitesi Yayınları, İstanbul, 2012, s. 124. 
Bundan başka, hükmün kaleme alınış biçimine göre ticari işletme niteliğinde olmayan esnaf işletmeleri TTK.m.1530 kapsamı dışında değerlendirilmek gerekir. Ancak yine hükmün amacı çerçevesinde yapılacak bir yorumla, esnaf işletmelerini tamamen hükmün kapsamı dışında tutmak yerine, bu konuda varılacak neticeyi somut olayda hâkimin takdirine birakarak gerektiğinde TTK.m.1530'un kıyasen uygulanabileceğini kabul etmek isabetli olur ${ }^{16}$.

\section{2. İşlemin para karşılığında mal ve/veya hizmet tedarikine ilişskin olması.}

Türk Borçlar Kanunu'nun genel hükümlerinde temerrüdün şartları açısından borcun türüne yönelik olarak bir ayrıma gidilmemiştir. Kural olarak her türlü borç için ihtarsız temerrüt ve bu arada borçlu temerrüdü söz konusu olabilir. Türk Borçlar Kanunu açısından hal böyle olmasına rağmen, TTK.m.1530/f.2'de taraflar arasında yapılan her türlü hukukî işlemden değil, "mal ve hizmet tedariki amacıyla" yapılan işlemlerden doğan alacaklardan bahsedilmektedir. Kanaatimizce TTK.m.1530/ f.2'deki "ve" bağlacına rağmen, sadece mal veya sadece hizmet ya da hem mal hem de hizmet tedariki amacıyla yapılan işlemlerin de madde kapsamında değerlendirilmesi yerinde olur. TTK.m.1530'da borçlu taraf bakımından ise "borcun ödenmemesi"nden söz edilmektedir. "Ödemek" ifadesi para borçları açısından kullanılan bir tabirdir. Şu halde borçlu bir miktar paranın ödenmesi ile yükümlü iken, bunun karşılığında alacaklı mal ve/veya hizmet tedarik etme borcu altına girecektir.

"Mal" kavramına her şeyden önce maddi varlığı olan şeyler girer. Bununla birlikte maddi varlığı olmayan şeylerin de bu kapsamda değerlendirilmesi mümkündür. Örneğin elektrik gücünün ya da müşteri çevresi hakkındaki bilgilerin satışında olduğu gibi. Doktrinde bazı yazarlar ${ }^{17}$ maddi varlığı olmayan fikrî hakları TTK.m. 1530'un kapsamı dışında görmektedir. Ancak bu hakların söz gelimi bir satış sözleşmesinden doğan borcun ifası amacıyla tamamen devredilmeleri dahi mümkün olabildiğine göre ${ }^{18}$, TTK.m.1530'daki "mal tedariki" kavramına dâhil edilmelerinde de kural olarak bir engel görülmemelidir. Buna örnek olarak bir miktar para karşılı̆ında telif hakkı veya patent hakkının devrinin borçlanılmasını konu edinen satış sözleşmeleri verilebilir. Öte yandan yapılan işlemin mutlaka malın mülkiyeti veya hakkın devrini konu edinmesi de gerekmez. Meselâ bir eğlence merkezine kira sözleşmesi kapsamında kullanımı bırakılan makinelerin kira bedelleri ödenmemişse, TTK.m.1530 uygulama alanı bulabilir. Keza mal ya da hizmet sağlama eser, hizmet veya isimsiz bir sözleşme uyarınca doğan borcun ifası amacıyla da gerçekleşebilir ${ }^{19}$.

"Hizmet" kavramına ise mal sağlama dışındaki her türlü işlem girer. Burada da edimin maddi varlığının bulunması zorunlu değildir. Örneğin haberleşme hizmetinin

\footnotetext{
${ }^{6}$ Netice bakımından bu yönde: Atamer/Okutan-Nilsson, s. 65. Hükümdeki ticari işletme kavramının gerek esnaf işletmesi gerekse serbest meslekle uğraşan kişileri kapsayacak şekilde, "iktisadi işletme" olarak anlaşılması gerektiği yönünde: Dural, s. 122.

17 Ataman/Okutan-Nilsson, s. 68; Ülgen v.d. (Ülgen), s. 316

18 Fikret Eren, Borçlar Hukuku Özel Hükümler, Ankara, Yetkin Yayınları, 2017, s. 32; Haluk Tandoğan, Borçlar Hukuku, Özel Borç İlişkileri, Cilt I/1, İstanbul, Vedat Kitapçılık, 2008, s. 102.

19 Dural, s. 121
} 
sağlanması, süpermarketin reyonlarının planlanması, yazılım şirketindeki güvenlik açıklarının tespitine yönelik faaliyetler gibi. Doktrinde bazı yazarlar ${ }^{20}$ hizmet kavramını iş görmeye indirgeme eğilimindedir. Bununla birlikte sigorta sözleşmesi gibi iş görme unsuru tartışma götürecek sözleşmelerin ${ }^{21}$ TTK.m.1530 kapsamında değerlendirilebileceği bu yazarlarca da ifade edilmektedir ${ }^{22}$.

3. Para alacaklısının kendi borcunu ifa etmiş olması. Türk Borçlar Kanunu'nun genel hükümlerinde öngörülen ihtarsız temerrüt hallerinin gerçekleşmesi için alacaklının kendi borcunu ifa etmiş olması zorunlu değildir. Meselâ sözleşmeye göre (A)'nın borcunun 1 Eylül'de, (B)'nin borcunun ise 1 Ağustos'ta vadesi gelse, 1 Ağustos geçmesine rağmen borcunu ifa etmeyen (B) temerrüde düşer. (A)'nın borcunu henüz ifa etmemiş olması kural olarak (B)'nin temerrüde düşmesine mani değildir. Hatta 1 Eylül gelmiş ve (A) da (B) de borcunu ifa etmemiş olsa, (B) kendiliğinden temerrütten kurtulmaz. $\mathrm{Bu}$ durumda (B) ancak ödemezlik definde bulunarak 1 Eylül tarihinden itibaren temerrütten kurtulma imkânına kavuşur ${ }^{23}$. Hâlbuki TTK.m.1530/f.2 uyarınca, “alacakll, kanundan veya sözleşmeden doğan tedarik borcunu yerine getirmiş" olmadıkça ihtarsız temerrüt gerçekleşmeyecektir. Yani kanun koyucu genel hükümlere göre çoğu defa bir defi hakkı şeklinde ortaya çıkan savunma imkânını, hakkın varlığına yönelik bir olgu haline getirerek itiraz mertebesine çıkarmıştır.

Bununla birlikte TTK.m.1530'da alacaklının borcu henüz muaccel hale gelmemişse, yine de söz konusu koşulun aranıp aranmayacağına ilişkin bir düzenleme bulunmamaktadır. Kanaatimizce alacaklının borcu muaccel hale gelmemiş olsa dahi, kendi borcunu ifa etmiş olması gerekir. Öte yandan alacaklı, yani mal veya hizmet tedariki borçlusu, kural olarak erken ifada bulunabilir ${ }^{24}$. Ancak alacaklı önceden haber vermeksizin erken ifada bulunmak istediği takdirde, para borçlusu ifayı hemen kabul etmemekte haklı görülebilir ${ }^{25}$.

Eğer para borçlusu usulüne uygun olarak yapılan ifayı haklı sebep olmaksızın reddetmiş ve alacaklı temerrüdüne düşmüşse, alacaklının TTK.m.1530'dan faydalanabilmesi için alacaklı temerrüdü hükümlerine göre şeyi tevdi etmesi gerekir.

20 Atamer/Okutan-Nilsson, s. 75; Ülgen v.d. (Ülgen), s. 316, N. 619.

21 Sigorta sözleşmelerinin sonuçları talih ve tesadüfe bağlı sözleşmeler grubuna girdiği görüşünde: Tandoğan, s. 6; Eren, Borçlar Özel, s. 22. Bunların geniş anlamda teminat sözleşmesi olduğu görüşünde: Cevdet Yavuz, Türk Borçlar Hukuku Özel Hükümler, 6098 sayılı Türk Borçlar Kanunu'na Göre Güncellenmiş ve Yenilenmiş 9. Baskıyı Hazırlayanlar: Cevdet Yavuz, Faruk Acar, Burak Özen, İstanbul, Beta, 2014, s. 19.

22 Atamer/Okutan-Nilsson, s. 76.

23 Defi hakkı ileri sürüldüğ̈̈ tarihten itibaren değil, hakkın doğumu anından itibaren temerrüdü ortadan kaldırır. Verilen örnekte (B) defi hakkını 1 Ekim'de dermeyan etse, temerrüdün sonuçları 1 Eylül tarihinden itibaren ortadan kalkacaktır. Ancak bu ihtimalde dahi temerrüdün 1 Ağustos - 1 Eylül tarihleri arasındaki sonuçlarına zarar gelmez. Zira (A)'nın borcu 1 Eylül tarihinde muaccel olduğundan defi hakkı da bu tarihte doğmuştur.

24 Şöyle ki, TBK.m.96 uyarınca, "Sözleşmenin hükümlerinden veya özelliğinden ya da durumun gereğinden tarafların aksini kastettikleri anlaşılmadıkça borçlu, edimini sürenin sona ermesinden önce ifa edebilir. Ancak, kanun veya sözleşme ya da âdet gereği olmadıkça borçlu, erken ifada bulunması sebebiyle indirim yapamaz."

25 Bkz. von Tuhr/Escher, s. 73. 
Yani burada alacaklı temerrüdünün oluşması TTK.m.1530'a başvurabilmek için tek başına yeterli değildir. Zira alacaklı temerrüdü ifanın yerini tutmaz; ancak tevdi ifanın yerini tutar.

Diğer yandan alacaklı tedarik borcunu yerine getirmemiş olsa dahi, borcunu yerine getirinceye kadar borçlunun genel hükümlere göre temerrüde düşürülmesinin önünde bir engel yoktur. Şu halde yukarıdaki örnek üzerinden gidilecek olursa, bir miktar para ödeme borcu altında olan (B)'nin borcunu 1 Ekim tarihinde, (A)'nın ise tedarik borcunu 15 Eylül'de yerine getirmiş olması varsayımında, (B)'ye karş1 15 Eylül tarihine kadar genel temerrüt hükümleri, 15 Eylül ila 1 Ekim tarihleri için ise (A)'nın tercihine bağlı olarak genel temerrüt hükümleri veya TTK.m.1530 kapsamında talepte bulunulabilir. Diğer yandan (B) ödemezlik definde bulunarak 1 Eylül - 15 Eylül tarihleri arasında mütemerrit sayılmaktan kurtulabilir.

4. Borçlunun gecikmeden sorumlu olması. Türk Borçlar Kanunu'nda objektif temerrüt teorisi kabul edilmiştir ${ }^{26}$. Buna göre borçlunun temerrüde düşmesi için kusurlu olması şart değildir. Mazur görülebilecek bir sebepten dolayı borcun varlığını bilmeyen ${ }^{27}$ ya da ihtar kendisine ulaşmasına rağmen kusursuz olarak bunu öğrenemeyen ${ }^{28}$ borçlu dahi kural olarak mütemerrit sayılabilir ${ }^{29}$.

Borçlunun kusurlu olarak temerrüde düşmesi, esas olarak temerrüt sebebiyle ondan tazminat istenebilmesi açısından önemlidir. Şöyle ki, borçlunun gecikme tazminatı ve beklenmedik hal sebebiyle meydana gelen zararlardan sorumlu tutulabilmesi için kusurlu olması şarttır. Keza, karşılıklı borç yükleyen sözleşmelerde ifadan vazgeçilmesi ya da sözleşmeden dönülmesi üzerine kanunun öngördüğü tazminatın istenebilmesi borçlunun mütemerrit sayılmakta kusurlu olmasına bağlıdır. Konumuz açısından önem arz eden para borçlarında da durum benzerdir. Bir miktar paranın ödenmesinde temerrüde düşen borçludan temerrüt faiziyle karşılanamayan aşkın zararın istenebilmesi için borçlu temerrüde düşmede kusurlu olmalıdır.

Buna karşılık temerrüdün bazı sonuçları borçlu kusursuz da olsa meydana gelir. Örneğin karşılıklı borç yükleyen sözleşmelerde borçlunun temerrüde düşmesi üzerine alacaklının TBK.m.123 ila 125 hükümlerinde öngörülen şartlar çerçevesinde sözleşmeden dönebilmesi için borçlunun kusurlu olması gerekmez. Aynı şekilde borçlu bir miktar paranın ödenmesinde kusursuz olarak temerrüde düşse dahi, kendisinden temerrüt faizi talep edilebilir.

Türk Borçlar Kanunu açısından vaziyet böyle olmasına rağmen TTK.m.1530/f.2’de para borcunu ödemede geciken borçlunun temerrüde düşmesi ve bu arada temerrüt

\footnotetext{
Eren, Borçlar Genel, s. 1098. İsviçre Borçlar Kanunu bakımından da vaziyet aynıdır: von Tuhr/Escher, s. 141.

von Tuhr/Escher, s. 142.

28 von Tuhr/Escher, s. 142 dn. 58.

29 von Tuhr/Escher, s. 142.
} 
faizinden sorumlu tutulabilmesi için kusurun gerekip gerekmediği noktasında farklı yorumlara yol açacak ifadelere yer verilmiştir. Şöyle ki, TTK.m.1530/f.2 uyarınca, borçlu, maddede öngörülen diğer koşulların da gerçekleşmesiyle birlikte, “... gecikmeden sorumlu tutulamayacağı hâller hariç, sözleşmede öngörülmüş bulunan tarihte veya belirtilen ödeme süresinde borcunu ödemezse, ihtara gerek olmaksızın temerrüde düşer.” Maddenin kötü kaleme alınmış ifadesi doktrinde tartı̧̧malara yol açmıştır $^{30}$. Bu bağlamda bazı yazarlar ${ }^{31}$, temerrüdün oluşumu için kusur şartı aramayan Türk Borçlar Kanunu sisteminden farklı olarak, TTK.m.1530/f.2'de temerrüt için kusur şartının öngörüldügünü ifade etmektedir. İkinci bir görüş̧ ${ }^{32}$, TTK.m.1530 kapsamında temerrüdün oluşması için kusur şartını aramamakta, fakat TTK.m.1530/f.7'de öngörülen kanunî temerrüt faizini aşan faiz ve alacağı tahsil masraflarından sorumluluk için kusurun aranması gerektiğini kabul etmektedir. Bu görüş uyarınca borçlu gecikmeden sorumlu tutulamıyorsa, genel hükümler çerçevesinde faiz talep edilmesi mümkündür. Üçüncü bir görüşe göre ${ }^{33}$, söz konusu ibare, "borçlunun davranışının objektif borca aykırı bir davranış niteliği taşımadığı haller hariç", şeklinde yorumlanmalıdır. Bu düşünceye katılınırsa, borçlunun gecikmeden sorumluluğu bakımından genel hükümlerden farklı bir koşul aranmayacak ve borçlu temerrüde düşmede kusursuz da olsa, TTK.m.1530 uyarınca sorumluluğu doğabilecektir. Nihayet son bir görüş is $\mathrm{e}^{34}$ borçlunun gecikmeden sorumlu tutulamayacağı halleri mümkün olduğunca dar yorumlayarak gecikmenin alacaklıya isnat edilebileceği hallerle sınırlandırmaktadır.

Kanaatimizce üçüncü görüşe üstünlük tanınmalıdır. $\mathrm{Bu}$ görüş Türk Borçlar Kanunu'nda düzenlenen temerrüt sistemine de uygundur. Şöyle ki, ifadaki her gecikme borçlunun sorumluluğunu gerektirmez. Ancak bir tür borca aykırılık hali olan temerrüdün koşullarının gerçekleşmesiyle birlikte, borçlu gecikmeden sorumlu tutulabilir. Maddede bu durum ifade edilmek istenmiştir. O halde TTK.m.1530/f.2 ve f.4 kapsamında borçlunun gecikmeden sorumlu tutulabilmesi için, Türk Borçlar Kanunu'nun genel hükümleri uyarınca kabul edilen borçlu temerrüdünün koşullarının gerçekleşmesi gerekir ${ }^{35}$.

Söz konusu koşulların gerçekleşmesi bakımından borçlar hukukunda kabul edilen prensipler kural olarak TTK.m.1530 açısından da geçerli olacaktır ${ }^{36}$. Bununla birlikte

30 Kendigelen'e göre (Kendigelen, s. 604 dn. 41) maddede yer alan söz konusu ifade iki şekilde yorumlanabilir. İlk olarak burada maddenin lafzına da uygun bir şekilde temerrüdün oluşumu için kusur şartının arandığı söylenebilir. İkinci olarak, temerrüdün oluşumu için değil, fakat TBK.m.1530/f.7'de belirlenen daha yüksek temerrüt faizi ve alacağın tahsili masraflarını talep bakımından kusurun şart olduğu ileri sürülebilir.

31 Ülgen v.d. (Ülgen), s. 318, N. 625; Reha Poroy/Hamdi Yasaman, Ticari İşletme Hukuku, İstanbul, Vedat Kitapç1lı, 2017 , s.171.

32 Çağlayan, s. 230-231.

33 Ayan, s. 774. Açık olmamakla birlikte bu eğilimde: Atamer/Okutan-Nilsson, s. 59.

34 İlhan Helvacı, "Türk Borçlar Kanunu’nun Borçlu Temerrüdüne ilișkin Genel Hükümleri ve Türk Ticaret Kanunu'nun Konuya İlişkin Bazı Hükümleri Üzerine”, Medeni Kanun'un 90. Yılı Uluslararası Sempozyumu, 1926'dan Günümüze Türk-İsviçre Medeni Hukuku, Ankara, Yetkin Yayınları, 2017, s. 224

35 Bu koşullar şu şekilde sayılabilir: ifanın mümkün olması, borcun muaccel olması, ihtarı lüzumsuz kılan bir durumun varlığı, borçlunun defi ileri sürmemiş olması, alacaklı temerrüdünün bulunmaması ve borçlunun usulüne uygun ifa teklifinin bulunmaması.

36 Bu prensipler için bkz. M. Kemal Oğuzman/M. Turgut Öz, Borçlar Hukuku Genel Hükümler, Cilt: 1, İstanbul, Vedat Kitapçılık, 2017, N. 1501 vd.; Mustafa Göktürk Yıldız, Türk Borçlar Kanunu’nun Genel Hükümlerine Göre Borçlu 
TBK.m.117/f.2'deki ihtarı lüzumsuz kılan durumların yerini, TTK.m.1530/f.2 ve f.4'te özel olarak düzenlenen ihtarsız temerrüt halleri alacaktır. Bunların uygulama alanının belirlenmesi ve genel hükümlerden ne ölçüde ayrıldığı konumuz açısından önem arz etmektedir.

\section{III. İhtarsız Temerrüt Halleri}

\section{A. Ödeme Gününün veya Süresinin Kararlaştırılmış Olması İhtimalinde}

1. TBK.m.117/f.2 Bakımından. TBK.m.117/f.2'ye göre, borcun ifa edileceği gün alacaklı ve borçlu tarafindan birlikte belirlendiği takdirde, bu günün geçmesiyle temerrüt ihtara gerek olmaksızın kendiliğinden gerçekleşir ${ }^{37}$. Bu hükmün uygulanması taraflarca kararlaştırılan vadenin belirli olmasına bağlıdır. Sözleşmede borcun ifa edileceği gün açıkça bir takvim günü olarak gösterilmiş ya da bu günün hangi takvim gününe karşılık geldiği borçlu tarafından kesin olarak hesaplanabiliyorsa belirli vade söz konusudur ${ }^{38}$. Ödemenin 1 Eylül 2018'de ya da sözleşmenin imzalanmasından sonra 15. günde yapılacağının kararlaştırılmasında olduğu gibi. Belirli vade ifanın belli bir süre içinde yapılacağı şeklindeki kayıtlarla da kararlaştırılabilir ${ }^{39}$. Ödemenin "sözleşmenin kurulmasından sonra 30 gün içinde" yapılacağının kararlaştırılmasında vaziyet böyledir. Bu gibi hallerde vade sürenin sonuncu gününe karşılık gelir ve son günün geçmesiyle temerrüt gerçekleşir. Aynı şekilde,

“2018 Ağustos ayında" ifa edilmesi gereken borcu 31 Ağustos’un bitimine kadar ifa etmeyen borçlu temerrüde düşer.

Doktrinde bazı yazarlara göre ${ }^{40}$, vadenin belirli olduğunun kabul edilebilmesi için takvim gününün sözleşmenin kurulduğu sırada bilinebilecek olması da zorunludur. İfa günü sözleşmenin kurulduğu sırada belirlenebilir olmayıp, ancak daha sonra ortaya çıkacak bir olguya veya meydana gelecek bir olaya dayanılarak tayin edilebilecekse, vade belirli olmayacağından borçluyu temerrüde düşürmek için ihtar gereklidir. Örneğin "fatura tarihinden itibaren 3 gün içinde", "malın tesliminden itibaren bir hafta içinde" gibi sözleşme kayıtlarıyla vade belirlenmişse, borçluyu temerrüde düşürmek için ihtarda bulunulması zorunludur ${ }^{41}$. Buna karşılık doktrinde diğer bir görüş ${ }^{42}$, alacaklının

Temerrüdünün Şartları ve Sonuçları, Yayımlanmamış Doktora Tezi, İstanbul Üniversitesi Sosyal Bilimler Enstitüsü, İstanbul, 2017, s. 4 vd.

37 Bu kural Roma Hukuku'nda "dies interpellat pro homine", yani "tarih insan yerine ihtar eder" şeklinde ifade edilmekteydi (von Tuhr/Escher, s. 138 dn. 31; Barlas, s. 54)

38 Oğuzman/Öz, N. 1519; Thévenoz, Art. 102, N. 26; von Tuhr/Escher, s. 138.

39 von Tuhr/Escher, s. 139; Thévenoz, Art. 102, N. 26.

40 H. Rolf Weber, Berner Kommentar, Bd. VI/1/5, Die Folgen der Nichterfüllung, Art. 97-109 OR, Bern, Stämpfli Verlag AG, Bern, 2000, Art. 102, N. 112; Melek Bilgin Yüce, Alacaklı ve Borçlu Açısından İfa Zamanı, İstanbul, Vedat Kitapçılık, 2015, s. 102; Barlas, s. 55-56.

${ }^{41}$ Bkz. Weber, Art. 102, N. 116; Barlas, s. 56.

42 Suat Sarı, "Belirli Vadenin Sözleşmenin Kurulduğu Ânda Belirlenebilir Olması Zorunlu Mudur?", Prof. Dr. Rona Serozan'a Armağan, C. II, İstanbul, 2010, s. 1583-1584. Netice olarak bu görüşte: Ataman/Okutan-Nilsson, s. 47 ve s. 53. 
ifa gününü muacceliyet ihbarı ile belirlediği hallerde TBK.m.117/f.2 uyarınca temerrüt ihtarının gerekmediğini dikkate alarak, tarafların kararlaştırdıkları vadenin sözleşmenin kurulduğu sırada belirlenebilir olmasının gerekli olmadığını kabul etmektedir. $\mathrm{Bu}$ görüşe katılınırsa, "faturanın tesliminden üç gün sonra ödeme" şeklindeki bir kaydın ihtar şartını bertaraf edeceği savunulabilecektir. Belirli vadenin varlığı için ifa zamanının sözleşmenin kurulduğu sırada bilinebilecek olması şeklindeki aksi görüş benimsenirse, fatura tesliminden sonra üç günün geçmesi yetmeyecek ve ayrıca ihtarda bulunulması da gerekecektir. Fakat bu gibi hallerde alacaklıya muacceliyet ihbarında bulunma yetkisi verildiği kabul edilerek faturanın teslimiyle bu yetkinin kullanıldığı söylenebiliyorsa, temerrüdün ihtarsız gerçekleştiği ileri sürülebilir.

Diğer yandan, "aşağı yukarı üç hafta içinde", "mümkün olan en kısa zamanda" gibi kayıtlar belirli vade olarak görülmemektedir ${ }^{43}$. Bu gibi hallerde vade kural olarak belirsizdir. Belirsiz vade kararlaştırılmışsa, temerrüdün gerçekleşmesi için ihtara gerek vardır ${ }^{44}$. Zira belirsiz vade TBK.m.117/f.2'deki istisnai düzenlemenin kapsamına girmez.

2. TTK.m.1530/f.2 bakımından. TBK.m.117/f.2 açısından temerrüdün ihtarsız gerçekleşmesi için vadenin belirli olması zorunlu olmakla birlikte benzer bir düzenleme

içeren TTK.m.1530/f.2'nin uygulanması bakımından farklı görüşler bulunmaktadır. Şöyle ki, TTK.m.1530/f.2'de, yukarıda saydığımız ön koşulların gerçekleşmesi üzerine, "sözleşmede öngörülmüş bulunan tarihte veya belirtilen ödeme süresinde" borcunu ödemeyen borçlunun ihtarsız olarak temerrüde düşeceği belirtilmiştir.

$\mathrm{Bu}$ düzenlemenin genel temerrüt hükümlerinden ayrılıp ayrılmadığı, eğer bir ayrılmanın olduğu kabul edilecekse bunun kapsamının ne olduğu hususunda doktrinde bir fikir birliği yoktur. Bazı yazarlar ${ }^{45}$ Türk Borçlar Kanunu'na göre temerrüt için ihtar şartının aranmadığı hallerde, TTK.m.1530/f.2 için de ihtar şartının aranmayacağını ve söz konusu düzenlemenin Türk Borçlar Kanunu hükümleri gereğince temerrüdün ihtarsız olarak gerçekleştiği hallerde bir değişiklik yapmadığını savunmaktadır. Buna karş1lı ikinci bir görüş ${ }^{46}$, hükümde yer alan "sözleşmede öngörülmüş bulunan tarihte veya belirtilen ödeme süresinde" şeklindeki ifadeden yola çıkarak, borçlar hukukunun genel prensiplerinden farklı olarak, vadenin belirli olmadığı hallerde de bu fikra uyarınca temerrüdün ihtarsız olarak gerçekleşebileceğini ileri sürmektedir. Bu noktada $\mathrm{Ayan}^{47}$ söz konusu düşüncenin aynen kabulünün mümkün olmadığını ve belirli vade kararlaştırılmış olmasa da, en azından ifa zamanının bir belirlilik taşıması

\footnotetext{
43 Bkz. von Tuhr/Escher, s. 139; Weber, Art. 102, N. 116.

44 Vade, gerçekleşeceği kesin olan, ancak ne zaman gerçekleşeceği bilinmeyen bir olaya bağlandığı takdirde, belirsizdir. Bu olayın gerçekleşme tarihinin "tahminen" söylenebilmesi sonucu değiştirmez (Weber, Art. 102, N. 114). "Ödeme turizm sezonu bitiminde yapılacaktır", "ödeme hasat zamanı yapılacaktır.” gibi sözleşme kayıtları belirsiz vadeye verilebilecek diğer örnekler olarak gösterilebilir (Benzer örnekler için bkz. Yüce, s. 139).

45 Ayan, s. 756.

46 Çağlayan, s. 219.

47 Ayan, s. 757.
} 
gerektiğini ifade etmektedir. Örneğin "havaların 1sınması", "en kısa zamanda" gibi ibareler ihtar şartını ortadan kaldırmaz. Fakat "faturanın teslimi anında ödeme" şeklindeki bir sözleşme kaydı için aksi sonuç kabul edilebilir ${ }^{48}$.

Kanaatimizce belirsiz vadenin TTK.m.1530/f.2 uyarınca temerrüt için ihtar şartını ortadan kaldıracağ fikri yerinde değildir. Buna gerekçe olarak TTK.m.1530/f.2 ile benzer bir ifadenin yer aldığı TTK.m.1530/f.3 gösterilebilir. Hükme göre, "Mütemerrit borçlunun alacaklisl sözleşmede öngörülen tarihten ya da ödeme süresinin sonunu takip eden günden itibaren, şart edilmemiş olsa bile faize hak kazanır. "Kanun koyucu ödeme süresinin son gününden bahsettiğine göre ortada takvim günü olarak hesap edilebilecek bir tarih yani belirli bir vade vardır. Ayrıca borçlunun temerrüde düştüğü tarih takvim günü olarak hesaplanmadan temerrüt faizi veya aşkın zararın tam olarak belirlenmesi de mümkün olamayacağından, aksi düşünce uygulamada sorunlara da yol açacaktır.

Doktrinde TTK.m.1530/f.2'nin uygulanması hakkında ileri sürülen üçüncü bir görüşe göre ${ }^{49}$, belirsiz vade söz konusu olduğu takdirde kural olarak ihtar şartı aranmalıdır. Ancak kimi zaman TTK.m.1530/f.4 kiyasen uygulanmak suretiyle ihtarın gerekmediği söylenebilecektir. Örneğin, "aracıllk faaliyeti sonucu sözleşme kurulursa ödeme" şeklinde bir sözleşme kaydının bulunduğu varsayımında, fatura düzenlenip borçluya yollanmışsa, bu andan itibaren otuz gün içinde, fatura düzenlenmemişse hizmetin teslim alındığı yani sözleşmenin kurulduğu andan itibaren otuz gün içinde temerrüt kendiliğinden gerçekleşir ${ }^{50}$. Esasında burada hemen yukarıda TBK.m.117/f.2 kapsamında ifade ettiğimiz belirli vadenin varlığ 1 için takvim gününün sözleşmenin kurulduğu sırada bilinebilir olmasının gerekip gerekmediği tartışmasına göre bir sonuca varmak gerekir ${ }^{51}$. Eğer TBK.m.117/f.2 kapsamında belirli vadenin varlığından söz edebilmek için takvim gününün sözleşmenin kurulduğu sırada bilinebilir olmasının zorunlu olmadığı görüşü kabul edilirse, "aracılık faaliyeti sonucu sözleşme kurulursa ödeme", "faturanın teslimi anında ödeme" gibi sözleşme kayıtları TTK.m.1530/f.2 kapsamında evleviyetle değerlendirilebilir. Ayrıca TTK.m.1530'un TBK.m.117'den farklı olarak zayıf tarafı korumak amacıyla düzenlendiği dikkate alınacak olursa, bu tür kayıtların varlığı durumunda temerrüdün ihtarsız gerçekleşeceği TBK.m.117/f.2'ye göre daha rahatlıkla söylenebilmelidir. Diğer yandan belirsiz vadenin söz konusu olduğu hallerde, kanaatimizce TTK.m.1530/f.4'ün doğrudan uygulanması mümkündür ${ }^{22}$.

Özetle, bize göre TTK.m.1530/f.2'de Türk Borçlar Kanunu'ndan farklı bir ihtarsız temerrüt hali düzenlenmemiştii ${ }^{53}$. Şu halde hükmün uygulanabilmesi için vadenin kural

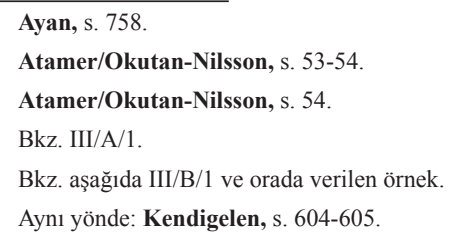


olarak belirli olması gerekir. Fakat hükmün amacı da göz önünde tutularak, vadenin belirli kabul edilebilmesi için ifa gününün hangi takvim gününe karşılık geldiğinin sözleşmenin kurulduğu sırada bilinebilir olmasını arayan görüş esnetilebilir. Diğer yandan TTK.m.1530/f.2'nin asıl anlamı TTK.m.1530/f.7'de ${ }^{54}$ öngörülen faiz oranının uygulanması bakımındandır. Buna göre borçlu "sözleşmede öngörülmüş bulunan tarihte veya belirtilen ödeme süresinde borcunu ödemezse”, TTK.m.1530/f.7'nin ve bu arada orada düzenlenen faiz oranının uygulanabilmesi mümkündür. Ancak temerrüt hükümde belirtilen hallerden biri sebebiyle değil de, örneğin ihtar sonucunda gerçekleştiği takdirde, TTK.m.1530/f.7'deki faiz oranları üzerinden hesaplama yapılması istenemez. Şüphe yok ki borçlu bu durumu kötüye kullanmış ve meselâ sözleşmede belirli bir vade öngörülmesini engellemişse, korunmayı hak etmez. Bu takdirde temerrüdün gerçekleşmesiyle birlikte TTK.m.1530/f.7'deki temerrüt faizi oranının uygulanması istenebilecektir.

\section{B. Ödeme Günü Veya Süresinin TTK.m.1530/f.2 Anlamında Kararlaştırılmamış Veya Kararlaştırılan Sürenin TTK.m.1530/f.5'e Aykırı Olması İhtimalinde}

1. Genel olarak. TTK.m.1530'da temerrüdün ihtarsız olarak gerçekleşeceğinin ifade edildiği bir diğer düzenleme de hükmün dördüncü fikrasında yer almaktadır. Bu düzenleme TTK.m.117/f.2'den bütünüyle farklı ihtarsız temerrüt halleri öngörmektedir.

Gerçekten de TTK.m.1530/f.4'e göre,

"Sözleşmede ödeme günü veya süresi belirtilmemişse veya belirtilen süre beşinci fikraya aykırı ise, borçlu aşağıdaki sürelerin sonunda ihtara gerek kalmaksızın mütemerrit sayılır ve alacakl faize hak kazanir:

a) Faturanın veya eş değer ödeme talebinin borçlu tarafindan alınmasını takip eden otuz günlük sürenin sonunda,

b) Faturanın veya eş değer ödeme talebinin alınma tarihi belirsizse mal veya hizmetin teslim alınmasın takip eden otuz günlük sürenin sonunda,

c) Borçlu faturayı veya eş değer ödeme talebini mal veya hizmetin tesliminden önce almışsa, mal veya hizmetin teslim tarihini takip eden otuz günlük sürenin sonunda,

d) Kanunda veya sözleşmede, mal veya hizmetin kabul veya gözden geçirme usulünün öngörüldügü hâllerde, borçlu, faturayı veya eş değer ödeme talebini, kabul veya gözden geçirmenin gerçekleştiği tarihte veya bu tarihten daha önce almışsa, bu tarihten sonraki otuz günlük sürenin sonunda; şu kadar ki, kabul veya gözden geçirme için sözleşmede öngörülen süre, mal veya hizmetin alınmasindan itibaren otuz günü aşıyor ve bu durum alacaklının aleyhine ă̆ır bir haksıllk oluşturuyorsa, kabul veya gözden geçirme süresi mal veya hizmetin alınmasindan itibaren otuz gün olarak kabul edilir.

Hüküm şu şekilde kaleme alınmıştır: "Bu madde hükümleri uyarınca alacaklyya yapılan geç ödemelere ilişsin temerrüt faiz oranının sözleşmede öngörülmediği veya ilgili hükümlerin geçersiz olduğu hâllerde uygulanacak faiz oranını ve alacağın tahsili masraftarı için talep edilebilecek asgari giderim tutarın Türkiye Cumhuriyet Merkez Bankası her yıl ocak ayında ilan eder. Faiz oranl, 4/12/1984 tarihli ve 3095 sayll Kanuni Faiz ve Temerrüt Faizine İlişkin Kanunda öngörülen ticari işlere uygulanacak gecikme faizi oranindan en az yüzde sekiz fazla olmalıdır." 
Hükümde yer alan "Sözleşmede ödeme günü veya süresi belirtilmemişse ..." şeklindeki ifade, vadenin TTK.m.1530/f.2 kapsamında belirlenmemiş olduğu haller olarak anlaşılmalıdır. Zira yukarıda da ifa ettiğimiz üzere sözleşmede ödeme günü veya süresi belirtilmişse vade belirlidir. Vadenin belirli olduğu hallerde TTK.m.1530/f.2 uygulanır. Şu halde TTK.m.1530/f.4 gerek sözleşmede vadenin hiç öngörülmediği gerekse belirsiz vadenin söz konusu olduğu hallerde tatbik edilebilir. Hükmün uygulanacağı bir diğer hal ise sözleşmede öngörülen vadenin belirli ya da belirsiz olmasına bakılmaksızın, TTK.m.1530/f.5'e aykırılık teşkil etmesidir ${ }^{55}$.

Şöyle ki, TTK.m.1530/f.5’te sözleşmede ödeme süresinin belirlenmesine ilişkin azami sınırlar öngörülmüştür. Bu sınırlar aşıldığı takdirde genel prensiplerden (ya da TTK.m.1530/f.1'de öngörülen çözümden) farklı olarak sadece azami haddi aşan kısım geçersiz sayılmayıp, kayıt tamamen geçersiz kabul edilerek doğrudan TTK.m.1530/f.4 uygulanacaktır. Örneğin vade olarak (X) gemisinin limana yanaşması tarihi belirlenmiş olup kanunda ya da sözleşmede malın kabul veya gözden geçirme usulü de bulunmamaktadır. Tarımsal üretici (A), hem faturayı hem de malı 20 Ağustos'ta süper market zinciri işletmecisi borçlu (B)'ye teslim etmiştir. (X) gemisi, 20 Kasım'da limana yanaşmış ve (B) halen borcunu ödememiştir. Burada temerrüt, TTK.m.1530/f.4, b. (a) kapsamında 20 Ağustos'u takip eden otuz günlük süre sonunda, yani 20 Eylül'de ihtarsız olarak gerçekleşir. Zira 20 Ağustos ile 20 Kasım arasında geçen süre altmış günü aştığından TTK.m.1530/f.5, c.son'a aykırı olup, TTK.m.1530/f.4 uygulanmalıdır ${ }^{56}$. Bu noktada bir an için 20 Eylül'de gemi limana henüz yanaşmadığından borcun muaccel hale gelmediği ve temerrüdün koşullarının oluşmadığı düşünülebilir. Ancak bu endişe yersizdir. Zira vadeye ilişkin kayıt geçersiz olunca borç vadesiz borca dönüşür ve TBK.m.90 uyarınca derhal muaccel olur.

Bundan başka, yukarıda TTK.m.1530/f.2 kapsamında saydığımız koşullar TTK.m.1530/f.4 için de aranmalıdır. Zira TTK.m.1530'un kendi içinde akışı, f.4 ile bu koşulları bertaraf etmenin değil, vade TTK.m.1530/f.2 kapsamında belirli olarak kararlaştırılmadığında devreye girecek ihtarsız temerrüt hallerinin öngörülmek istendiğini göstermektedir. Şu halde işlemin ticari işletmeler arasında mal veya tedarik amacıyla yapılması şarttır. Keza, alacaklının kendi borcunu ifa etmiş olması ve borçlunun gecikmeden sorumlu tutulması da gerekir. Bununla birlikte, TTK.m.1530/ f.2'de ödemenin kararlaştırılan tarihte veya sürede gerçekleştirilmemesi şeklinde ifade edilen ihtarsız temerüt halinin yerini, TTK.m.1530/f.4'te sayılan haller alacaktır.

\footnotetext{
TTK.m.1530/f.5'e göre, “Sözleşmede öngörülen ödeme süresi, faturanın veya eş değer ödeme talebinin veya mal veya hizmetin alındığ veya mal veya hizmetin gözden geçirme ve kabul usulünün tamamlandığı tarihten itibaren en fazla altmış gün olabilir. Şu kadar ki, alacakl aleyhine ağır bir haksız durum yaratmamak koşuluyla ve açıkça anlaşmak suretiyle taraflar daha uzun bir süre öngörebilirler. Ancak alacaklının küçük yahut orta ölçekli işletme (KOBI) veya tarımsal ya da hayvansal üretici olduğu veya borçlunun büyük ölçekli işletme sıfatını taşıdı̆ğ hâllerde, ödeme süresi, altmış günü aşamaz." Burada altmış günlük süreyi aşan sürelerin alacaklı aleyhine ağır bir haksız durum yaratıp yaratmadığı dürüstlük kuralı ve işlerdeki teamüller çerçevesinde belirlenecektir.

56 TTK.m.1530/f.5, c.son'a aykırı kayıtların kesin hükümsüz kabul edilerek TTK.m.1530/f.4'ün uygulanması gerektiği yönünde bkz. Poroy/Yasaman, s. 169; Dural, s. 123-124.
} 


\section{Fatura veya Eş Değer Ödeme Talebinin Borçlu Tarafından Alınmasına Bağlı Olarak İhtarsız Temerrüdün Gerçekleşmesi}

a. Genel olarak. TTK.m.1530/f.4 uyarınca, belli olgulardan sonra otuz gün sonunda ihtarsız temerrüdün gerçekleşebilmesi için, faturanın veya eş değer ödeme talebinin borçlu tarafından alınması, diğer bir deyişle borçluya ulaştırılması zorunludur ${ }^{57}$. Zira hükmün ifadesine dikkat edilecek olursa, faturanın veya eş değer ödeme talebinin borçluya iletilmesi dört bentte sayılan hallerin tamamı için de aranan bir unsurdur. Buna karşılık otuz günlük süre kimi zaman faturanın veya eş değer ödeme talebinin borçluya ulaştırılmasından itibaren değil, başka olguların gerçekleşmesinden itibaren başlamaktadır. Doktrinde faturanın veya eş değer ödeme talebinin gönderildiği ve borçluya ulaştığı hususlarını ispat yükünün, bundan lehine haklar çıkaran alacaklıda olduğu ifade edilmektedir ${ }^{58}$.

b. Temerrüdün gerçekleşeceği an. TTK.m.1530/f.4'e göre, borçlu fatura veya eş değer ödeme talebini mal veya hizmetin tesliminden sonra almışsa ve fatura veya eş değer ödeme talebinin borçluya ulaştığı tarih de belliyse, hükmün (a) bendi uygulanır ve temerrüt bunlardan birinin borçluya ulaşma tarihini takip eden otuz günlük sürenin sonunda gerçekleşir. Şayet borçlunun fatura veya eş değer ödeme talebini aldığı tarih belli değilse ya da borçlu bunlardan birini mal veya hizmetin tesliminden önce almışsa, otuz günlük süre mal veya hizmetin teslim edilmesini takip eden günden itibaren başlar (TTK.m.1530/f.4 b. (b) ve (c)). Doktrinde bazı yazarlar ${ }^{59}$ hem borçlu hem de alacaklının faturanın veya eş değer ödeme talebinin mal ya da hizmetin tesliminden sonra ulaştığını iddia etmesi, ancak bu tarihin belirsiz olması durumunda, alacaklının ileri sürdüğü tarihin esas alınması gerektiğini kabul etmektedirler. Esasında bu bir ispat sorunudur. Şu halde kanaatimizce borçlu ikrarda bulunarak alacaklının ileri sürdüğü tarihi kabul etmediği sürece, kural olarak malın veya hizmetin teslim edildiği tarih esas alınarak otuz günlük süre hesap edilmelidir.

Diğer yandan TTK.m.1530/f.4, b. (d)'de kanunda veya sözleşmede malın veya hizmetin teslimi için kabul veya gözden geçirme usullerinin öngörülmesi ihtimaline ilişkin olarak özel bir düzenleme kabul edilmiştir. Buna göre borçlu, " faturayı veya eş değer ödeme talebini, kabul veya gözden geçirmenin gerçekleştiği tarihte veya bu tarihten daha önce almışsa” kabul veya gözden geçirmenin tamamlandığg tarihten sonraki otuz günlük sürenin sonunda temerrüt ihtarsız olarak gerçekleşecektir. Aynı düzenlemede, malın veya hizmetin kabulü veya gözden geçirilmesi için sözleşme ile öngörülebilecek süreye üst sınır getirilmiştir. Şöyle ki, “...kabul veya gözden geçirme için sözleşmede öngörülen süre, mal veya hizmetin alınmasından itibaren otuz günü aşıyor ve bu durum alacaklının aleyhine ağır bir haksıllk oluşturuyorsa,

\footnotetext{
Ayan, s. 761.

58 Ayan, s. 761.

59 Atamer/Okutan-Nilsson, s. 40.
} 
kabul veya gözden geçirme süresi mal veya hizmetin alinmasindan itibaren otuz gün olarak kabul edilir." Burada otuz günü aşan sürelerin haksız olup olmadığı edimin niteliği, dürüstlük kuralı ve işlerdeki teamüllere göre değerlendirilecektir. Meselâ çabuk bozulacak nitelikte veya fiyatı çabuk düşen bir tarımsal ürün söz konusu ise, otuz günlük sürenin haksız olduğu söylenebilecektir. Diğer yandan öngörülen sürenin otuz günü aşmamasına rağmen alacaklı aleyhine haksız olması da söz konusu olabilir. $\mathrm{Bu}$ takdirde vakit kaybetmeksizin gözden geçirme usulünü tamamlamayan borçlunun dürüstlük kuralı gereği ifayı kabul etmiş sayılacağı düşünülebilir. Keza, malın veya hizmetin gözden geçirme amacına aykırı olarak kullanılması da kabul anlamına gelir. Meselâ alınan ürünlerin reyonlara yerleştirilmesinde olduğu gibi. Ancak kimi zaman mal veya hizmetin niteliği gereği gözden geçirmeyi gerçekleştirebilmek için süreyi uzun tutmak gerekebilir. Örneğin bir binanın sıcaklığa karşı yeterince tecrit edilip edilmediğini anlamak için sıcaklığın belli bir dereceye yükselmesini beklemek lazımdır.

Doktrinde bazı yazarlar ${ }^{60}$, TTK.m.1530/f.4, b. (d)'deki "kabul veya gözden geçirme" ifadesini, malın ya da hizmetin ayıplı olup olmadığının belirlenmesi için borçluya tanınan ayıpları gözden geçirme ve ihbar süreleri ile bağdaştırmaktadır. Bu görüsşe göre özellikle satış sözleşmesi bakımından TTK.m.23/b. (c)'de öngörülen 2 ve 8 günlük süreler uygulanabilecektir. Bu konuda verilen örneklerden biri şudur ${ }^{61}$ : Taraflar kabulün gözden geçirmeden sonra yapılacağını kararlaştırmış, fakat gözden geçirmeye ilişkin süre öngörmemişlerdir. Şayet malda açık bir ayıp varsa bu durum satıcıya 2 gün içinde bildirilmelidir. Bu bildirimden sonra sözleşmeden dönme hakk1 kullanılmadığ takdirde, bildirimi takip eden otuzuncu gün sonunda temerrüt ihtarsız gerçekleşecektir. Eğer ayıp gizliyse ve gözden geçirme gerekliyse, gözden geçirme süresi 8 gün kabul edilecektir. Bundan sonra eklenecek 30 gün sonunda temerrüt yine kendiliğinden gerçekleşecektir.

Kanaatimizce malın veya hizmetin ayıpsız olduğu anlaşılırsa ve mal ya da hizmet gözden geçirme süresi içinde yararlanılabilecek türden bir şeyse, fiilen kullanma olmasa dahi otuz günlük sürenin TTK.m.1530/f.4, b. (a), (b) ve (c) çerçevesinde hesap edilmesi gerekir. Zira borçlu şeyden yarar sağlamasına rağmen, borcunu sözleşmeye uygun olarak ifa eden alacaklının temerrüt faizinden mahrum bırakılması kanunun amacina aykırı olur.

Diğer yandan kanunda veya sözleşmede kabul ya da gözden geçirme süresi varsa ve mal veya hizmet bu sürelerin sonunda kabul edilmişse, otuz günlük süre kabul tarihinden itibaren işletilecektir. Borçlu, diğer bir deyişle mal veya hizmet alacaklısı, bu süreler dolmasına rağmen mal veya hizmeti kabul edip etmediğini derhal bildirmezse, ifayı kabul etmiş sayılır. Şayet mal veya hizmet kanunda ya da sözleşmede belirtilen kabul veya gözden geçirme süresi dolmadan kabul edilmişse,

\footnotetext{
A0 Atamer/Okutan-Nilsson, s. 42; Çağlayan, s. 228;

${ }^{61}$ Atamer/Okutan-Nilsson, s. 43.
} 
kabul tarihinden sonra otuz gün içinde temerrüt gerçekleşir. Bu son halde kabul veya gözden geçirme sürelerinin dolmamış olması sonuca etki etmez.

\section{TTK.m.1530/f.4’ün Genel Hükümler Uyarınca Temerrüdün Oluşmasına} Engel Teşkil Etmemesi. TTK.m.1530/f.4'te ihtarsız temerrüt hallerinin öngörülmüş olmas1, genel hükümlere göre temerrüdün oluşmasına engel değildir ${ }^{62}$. Fakat temerrüt TTK.m.1530/f.4'de öngörülen durumlar neticesinde kendiliğinden değil de, örneğin ihtar sonucunda genel hükümler uyarınca gerçekleşmişse, TTK.m.1530/f.7'deki faiz oranı uygulanamayacaktır. Bununla birlikte temerrüt faizinin TTK.m.1530/f.4'teki hallerden birinin gerçekleşmesi anına kadar genel prensiplere göre, bu hallerin gerçekleşmesinden itibaren ise TTK.m.1530/f.7'ye göre hesaplanması mümkün olmalıdır ${ }^{63}$. Örneğin 1 Nisan'da muaccel olan borç için alacaklı aynı gün borçluya hem ihtarda bulunmuş hem de faturayı ona ulaştırmış; fakat borçlu borcunu 1 Haziran'da ödemiştir. Böyle bir durumda, sözleşmede temerrüt faizi oranı öngörülmemişse, 1 Mayıs'a kadar 3095 sayılı Kanun'a göre, 2 Mayıs'tan itibaren ise TTK.m.1530/f.7'ye göre temerrüt faizi uygulanması talep edilebilir. Zira genel hükümlere göre temerrüt 1 Nisan'da meydana gelmiştir. Ayrıca 1 Mayıs'ın geçmesiyle birlikte faturanın alınmasından itibaren otuz günlük süre dolmuş ve TTK.m.1530/f.4, b. (a)'da belirtilen ihtarsız temerrüt hali gerçekleşmiştir.

\section{Fatura veya Eş Değer Ödeme Talebinde Gerçek Anlamda Bir Ödeme} Talebinin Yer Almasının Gerekmemesi. Türk Borçlar Kanunu'nun genel hükümlerine göre,

borçluya ulaştırılan faturanın temerrüdü gerçekleştirebilmesi için ödeme talebi içermesi, meselâ "ödenmiştir” kaydı taşıması gerekir. Bu bağlamda TTK.m.1530/ f.4'ün uygulanabilmesi için de borçluya ulaştırılan fatura veya eş değer ödeme talebinde gerçek anlamda bir ödeme talebinin bulunmasının gerekip gerekmediğinin açıklığa kavuşturulması önem arz etmektedir.

Kanaatimizce bu hususta iki şekilde değerlendirme yapmak mümkündür. İlk olarak, düzenleme kapsamında ele alınabilecek bir faturanın veya eş değer ödeme talebinin mevcudiyeti için de genel prensiplere uygun bir şekilde ödeme talebi içermeleri gerektiği ileri sürülebilir ${ }^{64}$. Fakat bu nitelikte kayıt taşıyan fatura veya eş değer ödeme talebi genel prensiplere göre borçluya ulaştığı anda onu temerrüde

\footnotetext{
Bkz. ve karş. Ayan, s. 760.

63 Bu yönde: Saibe Oktay-Özdemir, "Türk Borçlar Kanunundaki Temerrüt ve Faiz Hükümleri Karşısında Türk Ticaret Kanunu m. 1530'da Getirilen İfa Zamanına İlişkin Düzenlemelerin Uygulama Alanı”, Prof. Dr. Hasan Erman'a Armağan, İstanbul, Der Yayınları, 2015, s. 699.

${ }^{64}$ Doktrinde genellikle kabul edildiği üzere ifa talebi içeren bir fatura ihtar niteliğinde sayılır. Kanaatimizce ifa talebin içermeyen bir faturanın, TTK.m.1530/f.4 çerçevesinde ihtar niteliğinde sayılması söz konusu olamaz (Aksi yönde: Çağlayan, s. 222). Her şeyden önce burada “ihtarsız” bir temerrüt halinin öngörüldügünü Kanun'un kendisi söylemektedir. Şu halde faturayı ihtar niteliğinde saymak kanunun ifadesiyle çelişen bir tutum olur. Diğer yandan doktrinde belirtildiği üzere (Ayan, s. 761 dn. 101; Atamer/Okutan-Nilsson, s. 39 dn. 23), eğer fatura ihtar sayılsaydı temerrüt faturanın ulaşmasıyla oluşurdu. Hâlbuki maddede temerrüdün daha sonraki bir anda oluşacağı öngörülmektedir.
} 
düşürür. Oysa TTK.m.1530/f.4, temerrüdün bunların alınmasından itibaren otuz günlük sürenin sonunda gerçekleşeceğini öngörmüştür. Kanun koyucunun söz konusu düzenlemeyi alacaklının konumunu iyileştirmek amacıyla kabul ettiği düşünülecek olursa, bu yorumun yerinde olmayacağı ileri sürülebilir. Bu iddiaya karşılık ise, daha genel nitelikteki temerrüt hükümlerine başvurmanın her zaman mümkün olduğu, otuz günlük sürenin tamamlanmasının TTK.m.1530 hükümlerinden yararlanmak, özellikle TTK.m.1530/f.7'deki yüksek faizi talep etmek için sağlanması gerekli bir koşul olduğu söylenebilir. İkinci bir yorum tarzı olarak, hükmün kapsamına giren hallerde, ödeme talebi içermeyen fatura veya eş değer ödeme talebinin alınmasının bile otuz günün sonunda borçluyu ihtarsız olarak temerrüde düşüreceği ve bu andan itibaren TTK.m.1530/f.7'deki faiz oranının uygulama alanı bulabileceği iddia edilebilir. Kanaatimizce bu son yorum üstün tutulmalıdır. Zira TTK.m.1530/f.4, b. (b), (c) ve (d)'den anlaşıldığı kadarıyla, kanun koyucu ödemenin talep edilmesine değil, fakat belli olguların gerçekleşmesine ihtarsız temerrüt sonucu bağlama amacındadır. Ayrıca maddede temerrüdün "ihtarsız" gerçekleşeceği ifade edilmektedir. Fatura veya eş değer ödeme talebinde ödeme talebine yer verilirse, temerrüt ihtarsız değil, ihtardan belli bir süre sonra geçekleşecektir. Şu halde alacakl1, ödeme talebi içermeyen bir fatura ya da eş değer ödeme talebi göndermiş olsa bile, kanunda öngörülen sürelerin sonunda temerrüt oluşacaktır. Buna karşılık ödeme talebi içeren bir fatura veya eş değer ödeme talebi gönderildiği takdirde, borçlu temerrüdü derhal gerçekleşir. Fakat TTK.m.1530/f.7'deki faiz oranı, ancak faturanın veya eş değer ödeme talebinin borçlu tarafından alınması üzerine kanunda belirtilen sürelerin geçmesiyle uygulanabilir.

\section{Sonuç}

Bu çalışmada vardığımız başlıca neticeleri kısaca aşağıdaki şekilde izah edebiliriz:

TTK.m.1530'da ihtarsız temerrüt hallerinin öngörülmesinin amacı zayıf tarafın korunmasıdır.

TTK.m.1530'da belirtilen ihtarsız temerrüt hallerin oluşumu için maddenin ikinci fikrasında bazı koşullar öngörülmüş̧ür. Bu koşullar; işlemin ticari işletmeler arasında olması, mal ve/veya hizmet tedariki amacıyla yapılmış olması, para alacaklısının kendi borcunu yerine getirmiş olması ve borçlunun gecikmeden sorumlu tutulmasıdır.

TTK.m.1530/f.2'de yer alan "ticari işletmeler arasında" şeklindeki ifade amaca uygun olarak yorumlanmalıdır. Buna göre söz konusu hüküm özellikle para borcunun borçlusunun büyük işletme, alacaklısının ise küçük işletme veya orta ölçekli işletme olması durumunda uygulanır. Bundan başka, her iki tarafın büyük işletme olması durumunda da hükmün uygulanması mümkündür. Diğer yandan para alacaklısı konumundaki tarımsal veya hayvansal üreticiler faaliyetlerini bir ticari işletme çerçevesinde yürütmese de TTK.m.1530'un ihtarsız temerrüde ilişkin düzenlemelerinden faydalanabilirler. 
TTK.m.1530/f.2'deki “mal ve hizmet tedariki” şeklindeki ifadeye rağmen, sadece mal ya da sadece hizmet yahut hem mal hem de hizmet tedariki amaciyla yapilan işlemler de hüküm kapsamında değerlendirilmelidir. Mal ya da hizmetin maddi varlı̆̆ının bulunması zorunlu değildir.

TTK.m.1530/f.2'de borçlunun temerrüde düşmede kusurlu olması bir koşul olarak aranmamıştır. Maddede yer alan "borçlunun gecikmeden sorumlu tutulamadığı haller hariç" şeklindeki ifadeyi, borçlunun borca aykırı olarak ifada gecikmesi yani Türk Borçlar Kanunu'nun genel hükümleri uyarınca temerrüdün ihtar dışındaki şartlarının gerçekleşmesi olarak anlamak gerekir.

TTK.m.1530/f.2'de borcun ifa edileceği günün sözleşmede kararlaştırılmış olması ihtarsız temerrüt hali olarak düzenlenmiştir. Burada vadenin belirli olması gerekmektedir. Şu halde söz konusu hükümde TBK.m.117/f.2'den farklı bir ihtarsız temerrüt hali öngörülmemiştir. Hükmün anlamı TTK.m.1530/f.7'de öngörülen faiz oranının uygulanması bakımındandır. Buna göre borçlu sözleşmede belirlenen ifa gününde borcunu ödemezse, TTK.m.1530/f.7'nin ve bu arada orada düzenlenen faiz oranının uygulanması istenebilir. Buna karşı1ık temerrüt hükümde belirtilen hallerden biri sebebiyle değil de, örneğin ihtar sonucunda gerçekleşirse, TTK.m.1530/f.7'deki faiz oranları üzerinden hesaplama yapılması istenemez. Bunun dürüstlük kuralından kaynaklanan istisnaları olabilir.

TTK.m.1530/f.4 sözleşmede hiç vade öngörülmediği ya da vadenin belirsiz olduğu yahut TTK.m.1530/f.5'e aykırı olarak belirlendiği hallerde uygulanır.

Teslim edilen malın veya hizmetin gözden geçirme sonucunda ayıpsız olduğu anlaşılırsa ve mal veya hizmet gözden geçirme süresi içinde yararlanılabilecek türden bir şeyse, fiilen kullanma olmasa dahi otuz günlük sürenin TTK.m.1530/f.4, b. (a), (b) ve (c) çerçevesinde hesap edilmesi gerekir.

TTK.m.1530/f.4 kapsamında ihtarsız temerrüt hallerinin oluşması için de TTK.m.1530/f.2'de kabul edilen koşulların gerçekleşmesi gerekir.

TTK.m.1530/f.4 hükmünün öngörülmüş olmas1, genel hükümlere göre temerrüdün oluşmasına engel değildir. Bununla birlikte temerrüt TTK.m.1530/f.4'de öngörülenler durumlar neticesinde kendiliğinden değil de, örneğin ihtar sonucunda genel hükümler uyarınca gerçekleşmişse, TTK.m.1530/f.7'deki faiz oranı uygulanamaz. Temerrüt faizinin, TTK.m.1530'daki koşulların gerçekleşmesi anına kadar genel hükümlere göre, TTK.m.1530'daki koşulların gerçekleşmesinden itibaren TTK.m.1530/f.7'ye göre hesaplanması imkân dâhilindedir.

TTK.m.1530/f.4'ün uygulanması açısından fatura veya eş değer ödeme talebinin içeriğinde, gerçek anlamda bir ödeme talebinin bulunması gerekmez. 


\section{Kisaltmalar Listesi}

art. : article.

b. : bent.

bkz. : bakını.

c. : cümle.

C : cilt.

dn. : dipnot.

f. : fikra.

karş. : karşılaştırınız.

KOBİ : küçük veya orta boyutlu işletme.

m. : madde.

N. : kenar numaras1.

par. : paragraph.

s. : : sayfa.

S. : say1.

TBK. : Türk Borçlar Kanunu.

TCC. : Turkish Commercial Code.

TCO. : Turkish Code of Obligations.

TTK. : : Türk Ticaret Kanunu.

v.d. : ve diğgerleri.

vd. : ve devam1. 


\section{Kaynakça}

Atamer, Yeşim M.; Okutan-Nilsson, Gül; "Para Alacaklısının Geç Ödemelere Karşı Korunmasına İlişkin Yeni TK M. 1530 Düzenlemesi ve Uygulama Alanı", Banka ve Ticaret Hukuku Dergisi, C XXIX, S 3'ten ayrı bas1, Y11 2013, s. 31-82

Ayan, Serkan; “6102 sayılı Türk Ticaret Kanunu'nun 1530. Maddesi Gereğince Borçlunun Temerrüdü”, Dokuz Eylül Üniversitesi Hukuk Fakültesi Dergisi (Prof. Dr. Burhan Ceyhan’a Armağan Özel Sayısı), C 12, Y1l 2010, s. 717-793.

Barlas, Nami; Para Borçlarının İfasında Borçlunun Temerrüdü ve Bu Temerrüt Açısından Düzenlenen Genel Sonuçlar, İstanbul, Kazancı Hukuk Yayınları No:105, 1992.

Çağlayan, Pınar; “Avrupa Birliği Yönergeleri ve Alman Hukukundaki Deneyimler Işı̆̆ında Mal ve Hizmet Tedarikinde Geç Ödemenin Sonuçları (TTK MD. 1530)”, Banka ve Ticaret Hukuku Dergisi, C XXVII, S 2, Y11 2011, s. 173-243.

Dural, H. Ali; “Ticari İşletmeler Arasındaki Mal ve Hizmet Tedariki Sözleşmelerine İlişkin Yeni Ticaret Kanunu’nun 1530. Maddesi”, Yeni Türk Ticaret Kanunu’nun Ticari İşletme Hukuku Alanında Getirdiği Yenilikler Sempozyumu (25-26 Kasım 2011), Kadir Has Üniversitesi Yayınları, İstanbul, 2012, s. 119-128.

Eren, Fikret; Borçlar Hukuku Genel Hükümler, Ankara, Yetkin Yayınları, 2015 (Kısaltma: Borçlar Genel).

Eren, Fikret; Borçlar Hukuku Özel Hükümler, Ankara, Yetkin Yayınları, 2017 (Kısaltma: Borçlar Özel).

Helvacı, İlhan; “Türk Borçlar Kanunu'nun Borçlu Temerrüdüne ilişkin Genel Hükümleri ve Türk Ticaret Kanunu'nun Konuya İlişkin Bazı Hükümleri Üzerine”, Medeni Kanun’un 90. Yılı Uluslararası Sempozyumu, 1926’dan Günümüze Türk-İsviçre Medeni Hukuku, Ankara, Yetkin Yayınları, 2017.

Kendigelen, Abuzer; Yeni Türk Ticaret Kanunu, Değişiklikler, Yenilikler ve İlk Tespitler, İstanbul, On İki Levha, 2012.

Nomer, Haluk Nami; "Haksız Fiil ile Sebepsiz Zenginleşmeden Doğan Alacaklarda Borçlunun Temerrüdü İçin İhtar Gerekir mi?”, Prof. Dr. Rona Serozan'a Armağan, Cilt II, İstanbul, On İki Levha, 2010, s. 1303-1313.

Oğuzman, M. Kemal; Öz, M. Turgut; Borçlar Hukuku Genel Hükümler, Cilt: 1, İstanbul, Vedat Kitapçılık, 2017.

Oktay-Özdemir, Saibe; “Türk Borçlar Kanunundaki Temerrüt ve Faiz Hükümleri Karşısında Türk Ticaret Kanunu m. 1530'da Getirilen İfa Zamanına İlişkin Düzenlemelerin Uygulama Alanı”, Prof. Dr. Hasan Erman'a Armağan, İstanbul, Der Yayınları, 2015, s. 677-700.

Poroy, Reha; Yasaman, Hamdi; Ticari İşletme Hukuku, İstanbul, Vedat Kitapçılık, 2017.

Sarı, Suat; “Belirli Vadenin Sözleşmenin Kurulduğu Ânda Belirlenebilir Olması Zorunlu Mudur?”, Prof. Dr. Rona Serozan'a Armağan, C. II, İstanbul, 2010, s. 1576 vd.

Tandoğan, Haluk; Borçlar Hukuku, Özel Borç İlişkileri, Cilt I/1, İstanbul, Vedat Kitapçılık, 2008.

Thévenoz, Luc; in Thévenoz, Luc (Ed.)/Werro, Franz (Ed.): Commentaire Romand, Code des obligations I, Art. 1-529 CO, Bâle, Helbing Lichtenhahn, 2012.

von Tuhr, Andreas; Escher, Arnold; Allgemeiner Teil des schweizerischen Obligationenrecht, Band II (mit Supplement), Schulthess Juristische Medien AG, 1984.

Ülgen, Hüseyin; Helvacı, Mehmet; Kendigelen, Abuzer; Kaya, Arslan; Nomer-Ertan, N. Füsun; Ticari İşletme Hukuku, İstanbul, On İki Levha, 2015.

Weber, H. Rolf; Berner Kommentar, Bd. VI/1/5, Die Folgen der Nichterfüllung, Art. 97-109 OR, Bern, Stämpfli Verlag AG, Bern, 2000.

Yavuz, Cevdet; Türk Borçlar Hukuku Özel Hükümler, 6098 sayılı Türk Borçlar Kanunu'na Göre Güncellenmiş ve Yenilenmiş 9. Baskıyı Hazırlayanlar: Cevdet Yavuz, Faruk Acar, Burak Özen, İstanbul, Beta, 2014.

Yıldız, Mustafa Göktürk; Türk Borçlar Kanunu'nun Genel Hükümlerine Göre Borçlu Temerrüdünün Şartları ve Sonuçları, Yayımlanmamış Doktora Tezi, İstanbul Üniversitesi Sosyal Bilimler Enstitüsü, İstanbul, 2017.

Yüce, Melek Bilgin; Alacaklı ve Borçlu Açısından İfa Zamanı, İstanbul, Vedat Kitapçılık, 2015. 